\title{
Elevated serum iron level is a predictor of prognosis in ICU patients with acute kidney injury
}

Jie Shu, Yufeng Hu, Xueshu Yu, Jiaxiu Chen, Wenwei Xu and Jingye Pan ${ }^{*}$ (iD

\begin{abstract}
Background: Accumulation of iron is associated with oxidative stress, inflammation, and regulated cell death processes that contribute to the development of acute kidney injury (AKI). We aimed to investigate the association between serum iron levels and prognosis in intensive care unit (ICU) patients with AKI.

Methods: A total of 483 patients with AKI defined as per the Kidney Disease: Improving Global Guidelines were included in this retrospective study. The data was extracted from the single-centre Medical Information Mart for Intensive Care III database. AKI patients with serum iron parameters measured upon ICU admission were included and divided into two groups (low group and high group). The prognostic value of serum iron was analysed using univariate and multivariate Cox regression analysis.
\end{abstract}

Results: The optimal cut-off value for serum iron was calculated to be $60 \mathrm{\mu g} / \mathrm{dl}$. Univariable Cox regression analysis showed that serum iron levels were significantly correlated with prognosis of AKI patients. After adjusting for possible confounding variables, serum iron levels higher than $60 \mu \mathrm{g} / \mathrm{dl}$ were associated with increases in 28-day (hazard [HR] 1.832; $P<0.001)$ and 90-day (HR 1.741; $P<0.001)$ mortality, as per multivariable Cox regression analysis.

Conclusions: High serum iron levels were associated with increased short- and long-term mortality in ICU patients with AKI. Serum iron levels measured upon admission may be used for predicting prognosis in AKI patients.

Keywords: Acute kidney injury, Iron, Predictor, Mortality

\section{Background}

Acute kidney injury (AKI) is a severe syndrome with high morbidity and significant mortality risk. It is a common complication in patients admitted to hospitals (10$15 \%$ of all hospitalizations) [1] and intensive care units (over 50\%) [2]. Increasing AKI severity is associated with a stepwise increase in mortality [2]. Given that no targeted therapy can reliably prevent or treat AKI, there is a necessity to choose appropriate biological indicators to

\footnotetext{
* Correspondence: wmupanjingye@126.com

Department of Intensive Care Unit, Wenzhou Medical University, Wenzhou, 325000 Zhejiang, People's Republic of China
}

predict the prognosis of AKI and enable adequate prevention and treatment.

Iron plays an essential role in many critical cellular functions such as hypoxia signalling, mitochondrial function, erythropoiesis, cell cycle progression, DNA synthesis and repair, and regulation of inflammation. Nevertheless, excess iron is toxic to cells and tissues, including the kidney, due to its ability to cause oxidative stress (OS) and mitochondrial dysfunction, promote inflammation, and regulate cell death [3].

OS, inflammation, and regulated cell death mechanisms are thought to have important roles in AKI [3]. Persistent OS, mitochondrial dysfunction, and

(c) The Author(s). 2020 Open Access This article is licensed under a Creative Commons Attribution 4.0 International License, which permits use, sharing, adaptation, distribution and reproduction in any medium or format, as long as you give appropriate credit to the original author(s) and the source, provide a link to the Creative Commons licence, and indicate if changes were made. The images or other third party material in this article are included in the article's Creative Commons licence, unless indicated otherwise in a credit line to the material. If material is not included in the article's Creative Commons licence and your intended use is not permitted by statutory regulation or exceeds the permitted use, you will need to obtain permission directly from the copyright holder. To view a copy of this licence, visit http://creativecommons.org/licenses/by/4.0/ The Creative Commons Public Domain Dedication waiver (http://creativecommons.org/publicdomain/zero/1.0/) applies to the data made available in this article, unless otherwise stated in a credit line to the data. 
inflammation are thought to promote the development of AKI to chronic kidney disease (CKD) [3]. The relationship between iron-related parameters and AKI has been confirmed in several preclinical trials, but few clinical trials researching the prognosis of AKI are available. Therefore, we hypothesized that elevated serum iron is positively associated with poor prognosis in patients with AKI. We thus, investigated the prognostic role of serum iron in short- and long-term mortality of ICU patients with AKI.

\section{Methods}

\section{Data sources}

The data in our study was acquired from a large, singlecentre database named Medical Information Mart for Intensive Care (MIMIC-III). It integrates the clinical information of 53,423 patients (aged 16 years or above) who were admitted to critical care units of the Beth Israel Deaconess Medical Centre in Boston, Massachusetts, from 2001 to 2012 [4]. Clinical information collected were coded data, interventions, demographic detail, laboratory test results, medications, and survival data.

\section{Study patients}

A total of 483 adult patients with AKI were included in the final analysis after excluding patients with missing serum iron measurements and repetitive admissions. The occurrence of AKI was defined by Kidney Disease: Improving Global Outcomes (KDIGO) when serum creatinine increased by greater than $50 \%$ from baseline or showed $0.3 \mathrm{mg} / \mathrm{dL}$ or more increase within $48 \mathrm{~h}$. Patients with AKI were divided into three stages as per KDIGO. Stage 1 patients were those whose creatinine increased by more than 1.5 times baseline or showed $0.3 \mathrm{mg} / \mathrm{dL}$ or more increase within any $48 \mathrm{~h}$ period, or whose urine volume was less than $0.5 \mathrm{ml} / \mathrm{kg}$ for $6-12 \mathrm{~h}$. Stage $2 \mathrm{pa}-$ tients were those whose creatinine increased by more than 2.0 times baseline or whose urine volume was less than $0.5 \mathrm{ml} / \mathrm{kg}$ for more than $12 \mathrm{~h}$. Stage 3 patients were those whose creatinine increased by more than 3.0 times baseline or increased to more than $4.0 \mathrm{mg} / \mathrm{dl}$, who required acute dialysis, or whose urine volume was less than $0.3 \mathrm{ml} / \mathrm{kg}$ for more than $24 \mathrm{~h}$.

Iron-related parameters measured on the first day after ICU admission such as serum iron, ferritin, and transferrin were acquired. For some patients from whom ironrelated parameters were repeatedly measured, the mean value was used. Other information including age (categorized into $16-59$ and 60 years or above), gender, comorbidities, stage of AKI, related treatment, other laboratory measurements, and survival data were extracted from the database. All the above data were extracted using structure query language (SQL).

\section{Outcomes}

The primary outcome was the association between serum iron levels and 28-day and 90-day mortality of ICU patients with AKI. The secondary outcomes included the roles of ferritin and transferrin in the prognosis of ICU patients with AKI.

\section{Statistical analyses}

We used the random forest model to impute missing data (Fig. S1 (see Additional file 1)) [5] and analysed the original and imputed data, respectively. ShapiroWilk tests were performed and density maps were drawn to determine the normality of the distribution of the continuous variables. Normally distributed continuous variables are reported as mean \pm standard deviation (SD), while skewed variables are expressed as medians and interquartile ranges (IQRs). AKI patients were stratified according to receiver operating characteristic (ROC) curve analysis (Fig. S2 (see Additional file 2)). The optimal cut-off value for serum iron was calculated to be $60 \mu \mathrm{g} / \mathrm{dl}$; thus, patients were divided into two groups (Low group: $<60 \mu \mathrm{g} / \mathrm{dl}$; High group: $\geq 60 \mu \mathrm{g} / \mathrm{dl}$ ) (more detail in Additional file 2). Boxplots were generated to show the correlation between serum iron levels and different types of survival status. Differences between the death group and survival group were assessed using a Wilcoxon test or ttest. We used log-rank tests to compare the 28-day and 90-day survival rates among different groups and expressed the results as Kaplan-Meier curves. Correlations between iron-related parameters and shortand long-term mortality were determined by the univariate Cox proportional hazards model. The variables analysed in univariate Cox proportional hazards model were selected based on clinical relevance. These variables were finally incorporated into multivariate Cox proportional hazards models to determine the independent effects of serum iron levels on shortand long-term mortality. The hazard ratio (HR) and its $95 \%$ confidence interval $(\mathrm{CI})$ were calculated. All comparisons were two-tailed, with $P<0.05$ considered significant. All statistical analyses were performed using R 3.5.1.

We conducted a sensitivity analyses with the cohort with missing data to further validate the primary outcomes.

\section{Results}

A total of 483 patients with AKI (246 males and $237 \mathrm{fe}$ males) who fulfilled the KDIGO criteria were included in the final analysis. The demographics, laboratory measurements, stage of AKI, related treatment, and comorbidities are shown in Table 1 (details on baseline characteristics of the original study cohort and baseline 
Table 1 Baseline characteristics of the interpolated study cohort

\begin{tabular}{|c|c|}
\hline Characteristics & Values \\
\hline Total & 483 \\
\hline \multicolumn{2}{|l|}{ Sex, $n(\%)$} \\
\hline Female & $237(49.1)$ \\
\hline Male & $246(50.9)$ \\
\hline \multicolumn{2}{|l|}{ Age, n (\%) (years) } \\
\hline $16-59$ & $196(40.6)$ \\
\hline$\geq 60$ & $287(59.4)$ \\
\hline \multicolumn{2}{|l|}{ Comorbidity, n (\%) } \\
\hline Congestive heart failure & $198(41.0)$ \\
\hline Hypertension & $255(52.8)$ \\
\hline \multicolumn{2}{|l|}{ SOFA score, $\mathrm{n}(\%)$} \\
\hline$<2$ & $39(8.1)$ \\
\hline$\geq 2$ & $444(91.9)$ \\
\hline \multicolumn{2}{|l|}{ Stage of AKI, n (\%) } \\
\hline Stage 1 & $114(23.6)$ \\
\hline Stage 2 & $115(23.8)$ \\
\hline Stage 3 & $254(52.6)$ \\
\hline RRT, n (\%) & $123(25.5)$ \\
\hline \multicolumn{2}{|l|}{ Iron group, n (\%) } \\
\hline Low iron group & $311(64.4)$ \\
\hline High iron group & $172(35.6)$ \\
\hline \multicolumn{2}{|l|}{ Laboratory measurements } \\
\hline Creatinine, mean (SD) (mg/dl) & $2.25(1.59)$ \\
\hline Transferrin, mean (SD) (mg/dl) & $160.90(58.41)$ \\
\hline Ferritin, mean (SD) (ng/ml) & $496.27(392.81)$ \\
\hline \multicolumn{2}{|l|}{ 28-day survival status, n (\%) } \\
\hline Non-death & $334(69.2)$ \\
\hline Death & 149 (30.8) \\
\hline 28-day survival times, mean (SD) & $22.34(9.52)$ \\
\hline \multicolumn{2}{|l|}{ 90-day survival status, n (\%) } \\
\hline Non-death & $292(60.5)$ \\
\hline Death & $191(39.5)$ \\
\hline 90-day survival times, mean (SD) & $61.76(37.19)$ \\
\hline
\end{tabular}

Values are presented as number (\%) and mean (SD). SOFA Score Sequential Organ Failure Assessment score, RRT Renal Replacement Therapy, SD standard deviation

characteristics of the patients in two groups after interpolation can be found in the electronic supplementary material, Tables S1 and S2 (see Additional file 3)). More than half the patients were older than 60 years. The majority of patients had Stage 3 AKI. Most patients had a sequential organ failure assessment (SOFA) score greater than 2 points. There were 311 patients in the low group and 172 patients in the high group. The values of transferrin and ferritin were $160.9 \pm 58.41 \mathrm{mg} /$ $\mathrm{dl}$ and $496.27 \pm 392.81 \mathrm{ng} / \mathrm{ml}$, respectively.
The total 28-day and 90-day mortality rates were 30.8 and $39.5 \%$, respectively (Table 2). As shown in the boxplots, significant associations were observed between the 28-day and 90-day survival status values and serum iron levels $(P<0.001$ and $P=0.0021$, respectively) (Fig. 1$)$. The 28-day and 90-day mortality risks increased as serum iron levels increased $(P<0.001$ and $P=0.0015$, respectively) (Fig. 2). After adjusting for possible confounding variables, significant correlations remained between high serum iron level and 28-day and 90-day mortality risks $(\mathrm{HR}=1.832,95 \%$ CI: $1.305-2.573$, $P<0.001 ; \mathrm{HR}=1.741,95 \% \mathrm{CI}: 1.285-2.358, P<0.001$, respectively) as per the multivariate Cox proportional hazards models (Tables 3 and 4). We also analysed the original cohort with missing data, and found similar result: 28-day and 90-day mortality increased in patients with high serum iron (Tables S3 and S4 (see Additional file 3)).With respect to the other iron-related measurements, transferrin was associated with increased survival rates in ICU patients with AKI $(\mathrm{HR}=0.996,95 \% \mathrm{CI}$ : $0.993-0.999, P=0.021 ; \mathrm{HR}=0.0994,95 \%$ CI: $0.991-$ 0.997, $P<0.001$, respectively), while ferritin had no significant correlation with 28 -day and 90-day mortality risks $(\mathrm{HR}=1.001,95 \% \mathrm{CI}: 1.000-1.001, P<0.05$; $\mathrm{HR}=$ 1.000, 95\% CI: $1.000-1.001, P>0.05$, respectively) (Tables 3 and 4).

\section{Discussion}

In this retrospective study, we investigated the association between high serum iron levels and increased short- and long-term mortality in ICU patients with AKI. Additional analysis showed that transferrin was associated with increased survival rates of ICU patients with AKI.

In the biomedical field, iron, an element essential for life, is a double-edged sword. Iron levels in the body are tightly controlled by cells and systems through the maintenance of a pool of iron available for biosynthetic purposes [6-8]. Plasma transferrin molecules safely carry the ferric state $\left(\mathrm{Fe}^{3+}\right)$ and supply it to cells associated with the abovementioned pool. Serum iron, i.e. transferrin bound iron (TBI), is the physiological source of circulating iron captured by cells on demand. Serum iron is delivered into cells and the metal is released into the cytosol as labile cell iron (LCI) [9]. The normal range of plasma transferrin saturation (TSAT) is usually $20-40 \%$ and rarely exceeds $60 \%$, except in systemic iron overload conditions such as in hereditary haemochromatosis [10]. In systemic iron overload, excess iron cannot be matched by sufficient unsaturated iron binding capacity and results in the formation of non-transferrin bound iron (NTBI). A portion of circulating NTBI is readily available to participate in redox cycling and is defined as labile plasma iron (LPI) [11-13]. LPI can infiltrate cells, 
Table 2 Survival outcomes of patients in different serum iron levels groups

\begin{tabular}{lllll}
\hline Outcomes & Total $(\boldsymbol{n}=483)$ & Low iron group $(\boldsymbol{n}=311)$ & High iron group $(\boldsymbol{n}=172)$ & $\boldsymbol{P}$ Value \\
\hline 28-day mortality, n (\%) & $149(30.8)$ & $78(25.1)$ & $71(41.3)$ & $<0.001$ \\
90-day mortality, n (\%) & $191(39.5)$ & $109(35.0)$ & $82(47.7)$ & 0.009
\end{tabular}

raise LCI and cause cellular iron overload. Thus, during systemic iron overload, an increase in serum iron may be followed by an increase in LPI when unsaturated iron binding capacity decreases. The potential mechanisms that elevate serum iron levels are significantly associated with mortality in severe AKI patients and may be related to LPI.

Catalytic iron, also known as LPI, is a transitional pool of NTBI. It readily participates in redox cycling and causes damage to cell membranes, proteins, and DNA through redox reaction such as the Fenton reaction [9, 13, 14]. The role of catalytic iron as a critical player in different types of AKI has been demonstrated in many animal models $[15,16]$. A study in a rat model of ischae$\mathrm{mia} /$ reperfusion injury (IRI) reported no significant changes in total iron, non-haem or ferritin iron levels, but a significant increase in catalytic iron level after reperfusion [17]. IRI models may possess possible selfprotection mechanisms for regulating iron homeostasis [18].

In a rat model of cisplatin-induced nephrotoxicity, a key role of iron in mediating tissue damage through hydroxyl radicals (or similar oxidants) was demonstrated [19]. Another study reported the protective effects of hydroxyl radical scavengers and iron chelators on penicillin-induced acute renal failure [20]. Moreover, the protective effect of iron chelator deferoxamine on renal function was identified in rat models [21]. Ikeda Y, et al. showed that restricting dietary iron could inhibit oxidative stress and inflammatory changes, thereby reducing renal tubular interstitial damage [22].

Recent years have seen research on iron-related measurements in humans. Several studies have shown that elevated levels of catalytic iron are associated with increased incidence of AKI triggered by different conditions [13, 23-26]. Hepcidin is an essential regulator of iron homeostasis; it reduces extracellular iron levels by downregulating iron absorption in the duodenum and ferroportin expression and cellular iron release in macrophages $[25,27]$. The protective role of hepcidin in AKI provides evidence of the key role of iron in mediating AKI [28]. A study involving 807 patients showed that plasma catalytic iron and hepcidin are possibly useful prognostic indicators for AKI patients [16]. At present, most studies focus on the relationships between ironrelated measurements and morbidity of AKI rather than mortality. Few studies have reported the roles of ironrelated measurements in mortality of AKI in humans. Our study found that high serum iron levels were significantly associated with short- and long-term mortality of patients with AKI. Clinically, serum iron levels measured upon admission may be used as prognostic markers for AKI, thereby enabling timely interventions aimed at reducing mortality.

In addition, our study found that transferrin was associated with increased survival rates of patients with AKI.
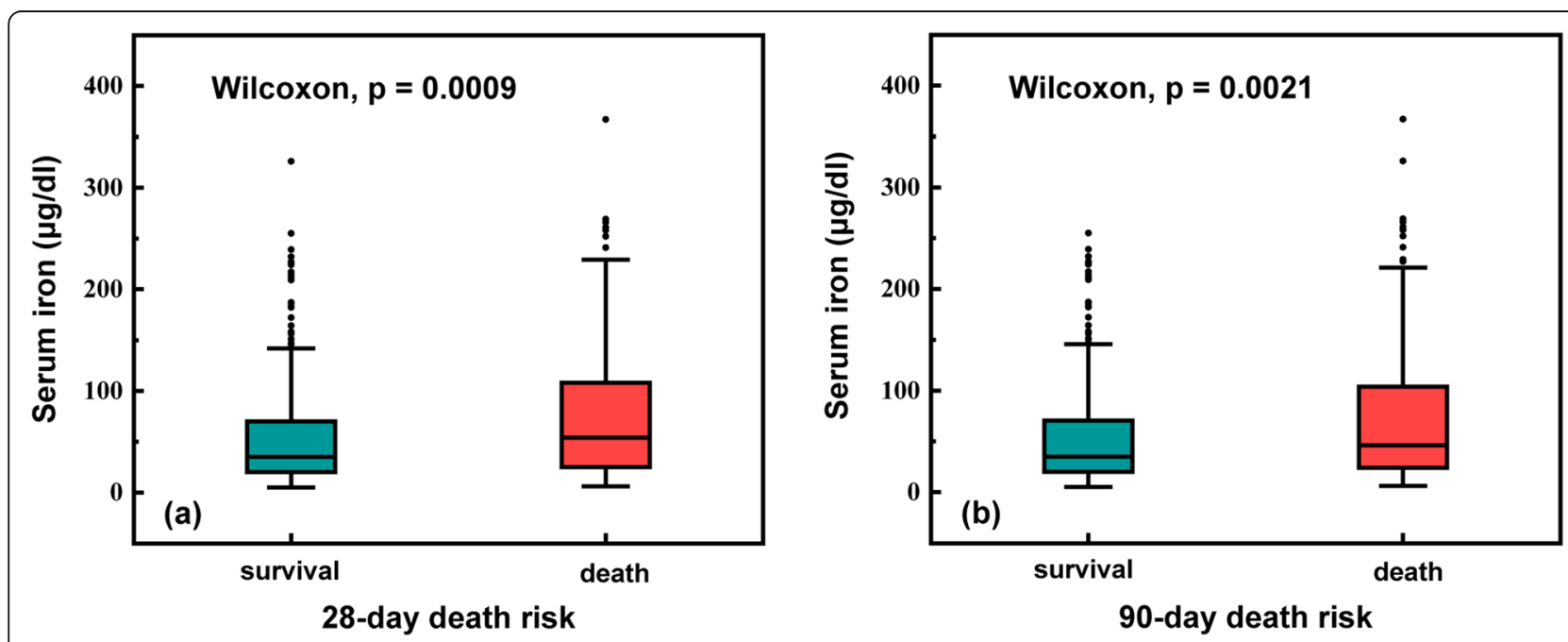

Fig. 1 Boxplots exploring the relationship between serum iron levels and different survival status. Serum iron levels were significantly higher in patients with death 


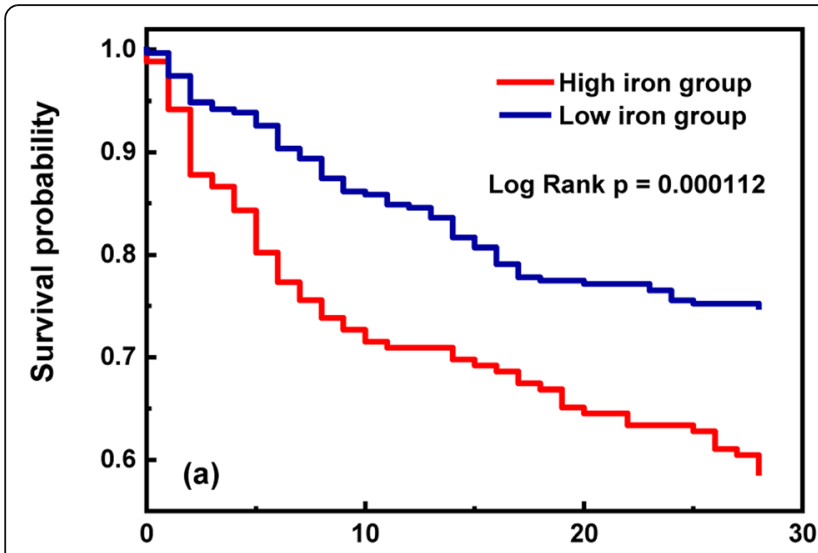

Day after admission

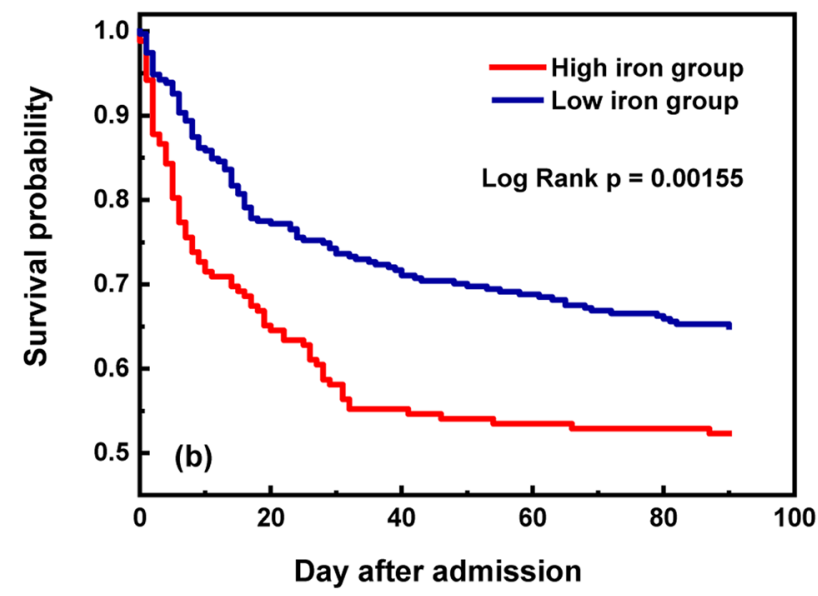

Fig. 2 Kaplan-Meier curves demonstrating the association of different serum iron levels and short- and long-term mortality. The short- and longterm mortality increased as serum iron levels increased

Transferrin is an iron-binding blood plasma glycoprotein that controls the level of free iron in body fluids. Recently, it has been shown to be a good indicator of organ failure; elevated transferrin levels have been associated with a reduction in the short-time mortality of patients with decompensated cirrhosis [29] and low serum transferrin levels have been associated with an increased risk in patients with sepsis [30]. As the main protein that binds and transports iron into the circulatory system, transferrin may decrease iron-mediated cell injury by

Table 3 Cox proportional hazards models exploring the relationship between serum iron levels and 28-day mortality

\begin{tabular}{|c|c|c|c|c|}
\hline \multirow[t]{2}{*}{ Factors } & \multicolumn{2}{|l|}{ Univariate model } & \multicolumn{2}{|l|}{ Multivariate model } \\
\hline & HR $(95 \% \mathrm{Cl})$ & $\boldsymbol{P}$ Value & $\mathrm{HR}(95 \% \mathrm{Cl})$ & $\boldsymbol{P}$ Value \\
\hline Sex (M) & $1.436(1.037-1.990)$ & 0.029 & $1.208(0.760-5.971)$ & 0.263 \\
\hline \multicolumn{5}{|l|}{ Age (years) } \\
\hline $16-59$ & Reference & - & Reference & - \\
\hline$\geq 60$ & $1.217(0.871-1.699)$ & 0.250 & $1.720(0.868-1.680)$ & 0.004 \\
\hline Congestive heart failure & $0.823(0.591-1.146)$ & 0.248 & $0.913(0.633-1.316)$ & 0.624 \\
\hline Hypertension & $0.759(0.550-1.047)$ & 0.093 & $0.717(0.510-1.010)$ & 0.057 \\
\hline \multicolumn{5}{|l|}{ SOFA score } \\
\hline$<2$ & Reference & - & Reference & - \\
\hline$\geq 2$ & 3.653 (1.353-9.866) & 0.011 & $2.130(0.760-5.971)$ & 0.151 \\
\hline \multicolumn{5}{|l|}{ Stage of AKI } \\
\hline Stage 1 & Reference & - & Reference & - \\
\hline Stage 2 & $1.231(0.709-2.136)$ & 0.461 & $1.152(0.661-2.006)$ & 0.618 \\
\hline Stage 3 & $2.131(1.353-3.356)$ & 0.001 & $1.543(0.919-2.589)$ & 0.101 \\
\hline \multicolumn{5}{|l|}{ Treatment } \\
\hline Non-RRT & Reference & - & Reference & - \\
\hline RRT & $1.663(1.186-2.334)$ & 0.003 & $1.008(0.653-1.556)$ & 0.972 \\
\hline Creatinine & $1.104(1.005-1.213)$ & 0.040 & $0.992(0.882-1.116)$ & 0.893 \\
\hline Transferrin & $0.993(0.990-0.996)$ & $<0.001$ & 0.996 (0.993-0.999) & 0.021 \\
\hline Ferritin & $1.001(1.001-1.001)$ & $<0.001$ & $1.001(1.000-1.001)$ & 0.029 \\
\hline \multicolumn{5}{|l|}{ Iron group } \\
\hline Low iron group & Reference & - & & - \\
\hline High iron group & $1.868(1.354-2.576)$ & $<0.001$ & $1.832(1.305-2.573)$ & $<0.001$ \\
\hline
\end{tabular}


Table 4 Cox proportional hazards models exploring the relationship between serum iron levels and 90-day mortality

\begin{tabular}{|c|c|c|c|c|}
\hline \multirow[t]{2}{*}{ Factors } & \multicolumn{2}{|l|}{ Univariate model } & \multicolumn{2}{|l|}{ Multivariate model } \\
\hline & $\mathrm{HR}(95 \% \mathrm{Cl})$ & $\boldsymbol{P}$ Value & HR $(95 \% \mathrm{Cl})$ & $\boldsymbol{P}$ Value \\
\hline Sex (M) & $1.524(1.142-2.034)$ & 0.004 & $1.308(0.976-1.753)$ & 0.072 \\
\hline \multicolumn{5}{|l|}{ Age (years) } \\
\hline $16-59$ & Reference & - & Reference & - \\
\hline$\geq 60$ & $1.44(1.065-1.947)$ & 0.018 & $1.910(1.372-2.661)$ & $<0.001$ \\
\hline Congestive heart failure & $1.012(0.759-1.348)$ & 0.936 & $1.115(0.812-1.531)$ & 0.502 \\
\hline Hypertension & $0.7821(0.589-1.039)$ & 0.090 & $0.703(0.520-0.951)$ & 0.022 \\
\hline \multicolumn{5}{|l|}{ SOFA score } \\
\hline$<2$ & Reference & - & Reference & - \\
\hline$\geq 2$ & $2.760(1.297-5.872)$ & 0.008 & $1.534(0.694-3.387)$ & 0.290 \\
\hline \multicolumn{5}{|l|}{ Stage of AKI } \\
\hline Stage 1 & Reference & - & Reference & - \\
\hline Stage 2 & $1.119(0.693-1.807)$ & 0.647 & $1.102(0.680-1.786)$ & 0.693 \\
\hline Stage 3 & $2.030(1.376-2.995)$ & $<0.001$ & $1.587(1.017-2.477)$ & 0.042 \\
\hline \multicolumn{5}{|l|}{ Treatment } \\
\hline Non-RRT & Reference & - & Reference & - \\
\hline RRT & $1.505(1.108-2.043)$ & 0.009 & $0.816(0.553-1.203)$ & 0.304 \\
\hline Creatinine & $1.112(1.023-1.208)$ & 0.0127 & $1.030(0.928-1.143)$ & 0.577 \\
\hline Transferrin & 0.992 (0.989-0.995) & $<0.001$ & $0.994(0.991-0.997)$ & $<0.001$ \\
\hline Ferritin & $1.001(1.001-1.001)$ & $<0.001$ & $1.000(1.000-1.001)$ & 0.086 \\
\hline \multicolumn{5}{|l|}{ Iron group } \\
\hline Low iron group & Reference & - & Reference & - \\
\hline High iron group & 1.585 (1.190-2.112) & 0.002 & $1.741(1.285-2.358)$ & $<0.001$ \\
\hline
\end{tabular}

HR Hazard Ratio, CI Confidence Interval, SOFA Sequential Organ Failure Assessment; AKI Acute Kidney Injury, RRT Renal Replacement Therapy

increasingly combining with overloaded iron. The potential mechanisms behind this require further investigation.

Ferritin, an iron binding protein whose function is to store iron in tissue, has the ability to sequester large amounts of intracellular iron and thereby prevent oxidative cellular damage [31]. In humans, there are conflicting reports on the role of ferritin in AKI. Several studies have demonstrated the protective effect of ferritin heavy chain on renal function [32, 33]. Some studies have shown that lower levels of ferritin are associated with increased morbidity of AKI after cardiopulmonary bypass [33, 34]. Dimitrijevic ZM, et al. reported that elevated serum ferritin levels favour renal function recovery [15], but this association was not observed in another study of 120 patients [35]. The latter observation was consistent with our study, in which ferritin had no significant correlation with mortality in ICU patients with AKI. Disturbances in cellular and systemic iron balance and AKI may affect each other as the kidney is an important player in preventing iron loss from the body by reabsorption [3]. Different tubular segments play different roles in handling iron; the proximal tubule has the maximum reabsorption capacity [36, 37]. The kidney reabsorbs iron, even when systemic iron levels are high [3]. Studies have shown that levels of catalytic iron in urine increased, rather than decreased, in AKI patients [38-40], but body iron stores are not low in AKI patients $[26,41]$. The iron-mediated mechanisms underlying AKI are complex and may include multiple pathways. Excess iron is associated with OS, and production of oxygen free radicals causes damage to lipids, DNA, and proteins [9]; renal tubular epithelial cells are particularly vulnerable to OS due to the high number of mitochondria in these cells [42]. In a rat model of acute ischaemia, mitochondrial dysfunction caused by OS was seen to lead to the production of proinflammatory cytokines [3]. Free iron can amplify the inflammatory response through the intracellular uptake and catabolism of damaged stored red blood cells via the monocytemacrophage system [43]. This is amplified by the fact that the inflammatory response is important in the pathogenesis of AKI [3, 44]. Iron-mediated OS, mitochondrial dysfunction, and inflammatory responses are possible mechanisms of AKI. Ferroptosis has also been considered a central player in AKI, characterized by the 
accumulation of lethal lipid ROS produced by ironmediated lipid peroxidation $[25,45,46]$. The excess iron in AKI may arise from degraded red blood cells, iron release from ferritin, and from mitochondria rich in haem and non-haem iron [47].

In terms of iron-targeted therapy for AKI, the therapeutic effects of hepcidin, deferoxamine, apolipoprotein, and pharmacologic therapy with apotransferrin and hydroxyl radical scavengers have been reported in animal models $[47,48]$. These results, in combination with those from our study, warrant further studies on iron-targeted therapy in patients with AKI.

Biochemical assessments of iron status iron-related indicators, such as serum iron, ferritin, transferrin and TAST have been conducted in several studies. However, the focus of the indicators has mainly been on deficiency states and measurements of iron repletion and overload have received little attention. The measurement of iron-related indicators is generally carried out on fully-automated clinical analysers. Serum iron is measured on chemical analysers through using a colorimetric reaction with ferrine or ferrozine as a chromogen to form a colour complex with iron, while protein-based indicators such as ferritin and transferrin are measured using immunoassays [49]. Whereas the abovementioned laboratory methods are widely available and provide good precision, the comparability of these results across different assay platforms still needs improvement. In addition, the serum iron levels in normal people exhibit diurnal variation, with higher values in the morning than in the afternoon [50]. The above factors may affect the accuracy of iron status measurements.

Our study has several limitations. First, this is a retrospective study with confounding bias due to missing values in the database and some indicators not being recorded in the MIMIC-III database. Second, MIMIC-III is a single-centre database with data between 2001 to 2012; therefore, even though the sample size of our study is large, the information may be relatively old. Third, we selected only one measurement of iron-related parameters on ICU admission as a research indicator and did not monitor the dynamic trend of serum iron level changes. Fourth, C-reactive protein (CRP) as a marker of inflammation is also important for the interpretation of various measured parameters. However, the MIMIC-III database lacks CRP data. In addition, serum iron levels might be influenced by haemolysis, intravenous iron therapy, blood transfusion and muscle damage. We were unable to obtain relevant data to adjust for these confounding effects, which might impact our results.

\section{Conclusions}

We clarified the relationship between elevated serum iron level and increased mortality in ICU patients with AKI and also investigated the protective effect of transferrin on prognosis of AKI. Serum iron levels can indicate the severity and prognosis of AKI and guide clinical decision making and monitoring of disease progression. Further clinical studies on iron-targeted therapy in AKI are required to better understand this process.

\section{Supplementary information}

Supplementary information accompanies this paper at https://doi.org/10. 1186/s12882-020-01965-9.

Additional file 1: Figure S1. Pattern of missing data in variables of interest.

Additional file 2: Figure S2. Receiver-operating characteristics (ROC) curve analysis of the best cut-off of serum iron.

Additional file 3: Table S1. Baseline characteristics of the original study cohort. Values are number (\%) and mean (SD). SOFA Score, Sequential Organ Failure Assessment score; RRT, Renal replacement therapy; SD, standard deviation. Table S2 Baseline characteristics of the patients in two groups after interpolation. Values are number (\%) and mean (SD). SOFA Score, Sequential Organ Failure. Assessment score; RRT, Renal replacement therapy; SD, standard deviation. Table S3. Cox proportional hazards models exploring the relationship between serum iron levels and 28-day mortality. Table S4. Cox proportional hazards models exploring the relationship between serum iron levels and 90-day mortality.

\section{Abbreviations}

AKl: Acute kidney injury; Cl: Confidence interval; CKD: Chronic kidney disease; CRP: C-reactive protein; HR: Hazard ratio; ICU: Intensive Care Unit; IQR: Interquartile range; IRI: Ischaemia/reperfusion injury; KIDGO: Kidney Disease: Improving Global Guidelines; OS: Oxidative stress; ROC: Receiver operating characteristic; RRT: Renal replacement therapy; SD : Standard deviation; SQL: Structure query language; TSAT: Transferrin saturation

\section{Acknowledgements}

Not applicable.

Authors' contributions

J.S. contributed to the design of the study and data extraction and analysis and drafted the manuscript. Y.H. and X.Y. assisted in data collection and analysis. J.C. and W.X. contributed to manuscript preparation. J.Y.P. designed and supervised this study and obtained funding. All authors read and approved the final manuscript.

Funding

Not applicable.

Availability of data and materials

The datasets used and/or analysed during the current study are available from the corresponding author upon reasonable request.

\section{Ethics approval and consent to participate}

This study was in accordance with the ethical standards of the Declaration of Helsinki and was approved by the institutional review boards of MIT and the Beth Israel Deaconess Medical Centre (researchers certification number 6335624, record id 23162528). MIMIC-III was retrospective with lack of patient intervention and all patients' data were de-identified, thus individual patient informed consent was not required.

Consent for publication Not applicable. 


\section{Competing interests}

All authors declare no competing interests.

\section{Received: 15 April 2020 Accepted: 17 July 2020} Published online: 25 July 2020

\section{References}

1. Al-Jaghbeer M, Dealmeida D, Bilderback A, Ambrosino R, Kellum JA. Clinical decision support for in-hospital AKI. J Am Soc Nephrol. 2018; 29(2):654-60.

2. Hoste EA, Bagshaw SM, Bellomo R, Cely CM, Colman R, Cruz DN, Edipidis K, Forni LG, Gomersall CD, Govil D, et al. Epidemiology of acute kidney injury in critically ill patients: the multinational AKI-EPI study. Intensive Care Med. 2015;41(8):1411-23.

3. van Swelm RPL, Wetzels JFM, Swinkels DW. The multifaceted role of iron in renal health and disease. Nat Rev Nephrol. 2020;16(2):77-98.

4. Johnson AE, Pollard TJ, Shen L, Lehman LW, Feng M, Ghassemi M, Moody B, Szolovits P, Celi LA, Mark RG. MIMIC-III, a freely accessible critical care database. Sci Data. 2016;3:160035

5. Stekhoven DJ, Bühlmann P. MissForest--non-parametric missing value imputation for mixed-type data. Bioinformatics (Oxford, England). 2012;28: $112-8$.

6. Wang J, Pantopoulos K. Regulation of cellular iron metabolism. Biochem J. 2011;434(3):365-81.

7. Rouault TA. The role of iron regulatory proteins in mammalian iron homeostasis and disease. Nat Chem Biol. 2006:2(8):406-14.

8. Ganz T. Systemic iron homeostasis. Physiol Rev. 2013;93(4):1721-41.

9. Slotki I, Cabantchik ZI. The labile side of Iron supplementation in CKD. J Am Soc Nephrol. 2015;26(11):2612-9.

10. Fleming RE, Ponka P. Iron overload in human disease. N Engl J Med. 2012; 366(4):348-59.

11. Cabantchik ZI. Labile iron in cells and body fluids: physiology, pathology, and pharmacology. Front Pharmacol. 2014;5:45.

12. Breuer W, Hershko C, Cabantchik Zl. The importance of non-transferrin bound iron in disorders of iron metabolism. Transfus Sci. 2000;23(3):185-92.

13. Leaf DE, Swinkels DW. Catalytic iron and acute kidney injury. Am J Physiol Renal Physiol. 2016:311(5):F871-6.

14. Swaminathan S. Iron, hormesis, and protection in acute kidney injury. Kidney Int. 2016:90(1):16-7.

15. Dimitrijevic ZM, Salinger-Martinovic SS, Jankovic RJ, Mitic BP. Elevated serum ferritin levels are predictive of renal function recovery among patients with acute kidney injury. Tohoku J Exp Med. 2019;248(2):63-71.

16. Leaf DE, Rajapurkar M, Lele SS, Mukhopadhyay B, Boerger EAS, Mc Causland FR, Eisenga MF, Singh K, Babitt JL, Kellum JA, et al. Iron, Hepcidin, and death in human AKI. J Am Soc Nephrol. 2019;30(3):493-504.

17. Baliga R, Ueda N, Shah SV. Increase in bleomycin-detectable iron in ischaemia/reperfusion injury to rat kidneys. Biochem J. 1993;291(Pt 3): 901-5.

18. Xie GL, Zhu L, Zhang YM, Zhang QN, Yu Q. Change in iron metabolism in rats after renal ischemia/reperfusion injury. PLoS One. 2017;12(4):e0175945.

19. Baliga R, Zhang Z, Baliga M, Ueda N, Shah SV. In vitro and in vivo evidence suggesting a role for iron in cisplatin-induced nephrotoxicity. Kidney Int. 1998;53(2):394-401.

20. Walker PD, Shah SV. Evidence suggesting a role for hydroxyl radical in gentamicin-induced acute renal failure in rats. J Clin Invest. 1988;81(2):33441.

21. PALLER MS. Hemoglobin- and myoglobin-induced acute renel faliure in rats: role of iron in nephrotoxicity; 2018

22. Ikeda $Y$, Horinouchi $Y$, Hamano H, Hirayama T, Kishi S, Izawa-Ishizawa Y, Imanishi M, Zamami Y, Takechi K, Miyamoto L, et al. Dietary iron restriction alleviates renal tubulointerstitial injury induced by protein overload in mice. Sci Rep. 2017;7(1):10621.

23. Leaf DE, Rajapurkar M, Lele SS, Mukhopadhyay B, Rawn JD, Frendl G, Waikar SS. Increased plasma catalytic iron in patients may mediate acute kidney injury and death following cardiac surgery. Kidney Int. 2015;87(5):1046-54

24. Balla J, Balla G, Zarjou A: Ferritin in Kidney and Vascular Related Diseases: Novel Roles for an Old Player. Pharmaceuticals (Basel). 2019;12(2):96.

25. Swaminathan S. Iron homeostasis pathways as therapeutic targets in acute kidney injury. Nephron. 2018;140(2):156-9.
26. David E. Leaf, Mohan Rajapurkar, Suhas S. Lele: Plasma Catalytic Iron, AKI and Death among Critically III Patients. 2014

27. Cho SY, Hur M. Hepcidin and neutrophil Gelatinase-associated Lipocalin as a biomarker for acute kidney injury linked Iron metabolism. Ann Lab Med. 2020;40(2):97-8

28. Scindia Y, Wlazlo E, Leeds J, Loi V, Ledesma J, Cechova S, Ghias E, Swaminathan S. Protective role of Hepcidin in Polymicrobial Sepsis and acute kidney injury. Front Pharmacol. 2019;10:615.

29. Bruns T, Nuraldeen R, Mai M, Stengel S, Zimmermann HW, Yagmur E, Trautwein C, Stallmach A, Strnad P. Low serum transferrin correlates with acute-on-chronic organ failure and indicates short-term mortality in decompensated cirrhosis. Liver Int. 2017;37(2):232-41.

30. Morath MA, Miller SF, Finley RK Jr. Nutritional indicators of postburn bacteremic sepsis. JPEN J Parenter Enteral Nutr. 1981;5(6):488-91.

31. Balla G, Jacob HS, Balla J, Rosenberg M, Nath K, Apple F, Eaton JW, Vercellotti GM. Ferritin: a cytoprotective antioxidant strategem of endothelium. J Biol Chem. 1992;267(25):18148-53.

32. Hatcher HC, Tesfay L, Torti SV, Torti FM. Cytoprotective effect of ferritin $\mathrm{H}$ in renal ischemia reperfusion injury. PLoS One. 2015;10(9): e0138505.

33. CONNIE L. DAVIS ATK, Richard a. ZAGER: Acute Renal Failure after Cardiopulmonary Bypass Is Related to Decreased Serum Ferritin Levels. 1999.

34. Choi N, Whitlock R, Klassen J, Zappitelli M, Arora RC, Rigatto C, Ho J. Early intraoperative iron-binding proteins are associated with acute kidney injury after cardiac surgery. J Thorac Cardiovasc Surg. 2019; 157(1):287-97 e282

35. Tuttle KR, Worrall NK, Dahlstrom LR, Nandagopal R, Kausz AT, Davis CL. Predictors of ARF after cardiac surgical procedures. Am J Kidney Dis. 2003; 41(1):76-83

36. Zhang D, Meyron-Holtz E, Rouault TA. Renal iron metabolism: transferrin iron delivery and the role of iron regulatory proteins. J Am Soc Nephrol. 2007;18(2):401-6.

37. Langelueddecke C, Roussa E, Fenton RA, Wolff NA, Lee WK, Thevenod F. Lipocalin-2 (24p3/neutrophil gelatinase-associated lipocalin (NGAL)) receptor is expressed in distal nephron and mediates protein endocytosis. J Biol Chem. 2012;287(1):159-69.

38. Akrawinthawong K, Shaw MK, Kachner J, Apostolov EO, Basnakian AG, Shah S, Tilak J, McCullough PA. Urine catalytic iron and neutrophil gelatinase-associated lipocalin as companion early markers of acute kidney injury after cardiac surgery: a prospective pilot study. Cardiorenal Med. 2013;3(1):7-16.

39. Biemond; SEvRAJRBJ: Iron handling by the human kidney: Glomerular filtration and tubular reabsorption both contribute to urinary iron excretion. Am J Physiol Renal Physiol. 2019:316(3):F606-14.

40. Anthony G.W, Norden ML, Philip J. Lee, Charles D. Pusey, Steven J. Scheinman, Frederick W.K, Tam, Rajesh V. Thakker, Robert J. Unwin, and Oliver Wrong: Glomerular protein sieving and implications for renal failure in Fanconi syndrome. Kidney Int. 2001;60(5):1885-92.

41. Blanchard A, Curis E, Guyon-Roger T, Kahila D, Treard C, Baudouin V, Berard E, Champion G, Cochat P, Dubourg J, et al. Observations of a large dent disease cohort. Kidney Int. 2016;90(2):430-9.

42. Liu BC, Tang TT, Lv LL, Lan HY. Renal tubule injury: a driving force toward chronic kidney disease. Kidney Int. 2018;93(3):568-79.

43. Van Avondt K, Nur E, Zeerleder S. Mechanisms of haemolysis-induced kidney injury. Nat Rev Nephrol. 2019;15(11):671-92.

44. Kanbay M, Vervloet M, Cozzolino M, Siriopol D, Covic A, Goldsmith D, Solak Y. Novel faces of fibroblast growth factor 23 (FGF23): Iron deficiency, inflammation, insulin resistance, left ventricular hypertrophy, proteinuria and acute kidney injury. Calcif Tissue Int. 2017;100(3):217-28.

45. Scindia PY, Leeds MDJ, Swaminathan MDS. Iron homeostasis in healthy kidney and its role in acute kidney injury. Semin Nephrol. 2019;39(1): 76-84.

46. Müller T, Dewitz C, Schmitz J, Schröder AS, Bräsen JH, Stockwell BR, Murphy $J M$, Kunzendorf $U$, Krautwald S. Necroptosis and ferroptosis are alternative cell death pathways that operate in acute kidney failure. Cell Mol Life Sci. 2017;74(19):3631-45.

47. Walker VJ, Agarwal A. Targeting Iron homeostasis in acute kidney injury. Semin Nephrol. 2016;36(1):62-70.

48. Scindia $Y$, Dey $P$, Thirunagari $A$, Liping $H$, Rosin DL, Floris M, Okusa MD, Swaminathan S. Hepcidin mitigates renal ischemia-reperfusion injury by 
modulating systemic Iron homeostasis. J Am Soc Nephrol. 2015;26(11): 2800-14.

49. Pfeiffer CM, Looker AC. Laboratory methodologies for indicators of iron status: strengths, limitations, and analytical challenges. Am J Clin Nutr. 2017; 106(Suppl 6):1606S-14S.

50. Coca SG, Yusuf B, Shlipak MG, Garg AX, Parikh CR. Long-term risk of mortality and other adverse outcomes after acute kidney injury: a systematic review and meta-analysis. Am J Kidney Dis. 2009;53(6): 961-73.

\section{Publisher's Note}

Springer Nature remains neutral with regard to jurisdictional claims in published maps and institutional affiliations.

Ready to submit your research? Choose BMC and benefit from:

- fast, convenient online submission

- thorough peer review by experienced researchers in your field

- rapid publication on acceptance

- support for research data, including large and complex data types

- gold Open Access which fosters wider collaboration and increased citations

- maximum visibility for your research: over $100 \mathrm{M}$ website views per year

At $\mathrm{BMC}$, research is always in progress.

Learn more biomedcentral.com/submissions 